\title{
THE INFLUENCE OF GENDER AND THE ENVIRONMENT OF ORIGIN ON THE FORMATION OF COGNITIVE SKILLS IN STUDENTS OF SPORTS CLASSES
}

\author{
Mariana ARDELEAN \\ University of Medicine, Pharmacy, Sciences and Technology of Târgu Mureş \\ mariana.ardelean@umfst.ro
}

\begin{abstract}
The research carried out investigated how the variables related to the gender (male/female) and the environment of the subjects (rural/urban) have an influence on the perception of new experimental methods implemented in order to develop the cognitive dimension skills in the "Theoretical sports training" discipline. The aim of the research is conducted following the criteria of gender analysis (girls, boys) and origin environment (rural, urban) involved in the way the subjects of the experiment class have perceived and adapted to the new methods implemented in the pedagogical experiment, by comparison with those in the control class.
\end{abstract}

Key words: rural environment, urban environment, male gender, female gender, experiment class, control class, evaluation.

\section{Introduction}

All the theoretical issues related to gender highlight two major perspectives: a biological one and a cultural one. In the educational system, gender-related investigative processes are just taking off, prescribing gender models in terms of social integration and professional development of schooled subjects [1].

The research study was carried out on a number of 55 pupils, coming from two classes of Suceava Sports High School. In the initial testing, the subjects were enrolled in the $10^{\text {th }}$ grade (academic year 2015-2016), in the intermediate testing they were in the $11^{\text {th }}$ grade (academic year 2016-2017), and in the final test they were in the $12^{\text {th }}$ grade (academic year 2017-2018). The experimental program included two independent classes, an experimental one, comprising 27 subjects, consisting of 12 girls and 15 boys, 5 subjects from the rural environment and 22 from the urban environment. The control class comprised 28 subjects, consisting of 14 girls and 14 boys, 19 from the rural environment, and 9 from the urban environment.

\section{Research Methods}

The scientific methods used in the research were: pedagogical experiment method, statisticalmathematical method of data processing, and tabular method.

\section{Results and discussions}

As a result of the processing of the data obtained, from a statistical and mathematical point of view [5, 6], the comparative results between the genre and the environment of the subjects in the experiment class (table 1) and the control class (table 2), in the initial, intermediate and final testing in "Theoretical sports training" discipline, presents a series of particularities.
Table 1. Comparative results between the genre and the provenience environment of the subjects in the experiment class, in the initial, intermediate and final testing $(n=27)$

\begin{tabular}{|c|c|c|c|c|c|}
\hline \multicolumn{6}{|c|}{ STATISTICAL INDICATORS BY GENDER } \\
\hline $\begin{array}{l}\text { Evaluation } \\
\text { forms }\end{array}$ & $\begin{array}{c}\text { Genre: } \\
\text { M / F }\end{array}$ & $n$ & $\begin{array}{c}\bar{X} \\
\pm m\end{array}$ & $t$ & $p$ \\
\hline \multirow{2}{*}{ Initial } & M & 15 & $\begin{array}{c}6,30 \\
\pm \\
0,33\end{array}$ & \multirow{2}{*}{1,55} & \multirow{2}{*}{0,05} \\
\hline & $\mathrm{F}$ & 12 & $\begin{array}{c}7,08 \\
\mathbf{\pm} \\
0,37\end{array}$ & & \\
\hline \multirow{2}{*}{ Intermediary } & M & 15 & $\begin{array}{c}6,70 \\
\pm \\
0,36\end{array}$ & \multirow{2}{*}{2,56} & \multirow{2}{*}{$<$} \\
\hline & $\mathrm{F}$ & 12 & $\begin{array}{c}8,00 \\
\pm \\
0,34\end{array}$ & & \\
\hline \multirow{2}{*}{ Final } & M & 15 & $\begin{array}{c}7,50 \\
\pm \\
0,35\end{array}$ & \multirow{2}{*}{1,48} & \multirow{2}{*}{$\begin{array}{c}> \\
0,05\end{array}$} \\
\hline & $\mathrm{F}$ & 12 & $\begin{array}{c}8,25 \\
\pm \\
0,34\end{array}$ & & \\
\hline \multicolumn{6}{|c|}{$\begin{array}{l}\text { STATISTICAL INDICATORS BY PROVENIENCE } \\
\text { ENVIRONMENT }\end{array}$} \\
\hline
\end{tabular}




\begin{tabular}{|c|c|c|c|c|c|}
\hline $\begin{array}{c}\text { Evaluation } \\
\text { forms }\end{array}$ & $\begin{array}{c}\text { Provenience } \\
\text { environment: } \\
\mathbf{R} \text { / U }\end{array}$ & $n$ & $\begin{array}{c}\bar{X} \\
\pm m\end{array}$ & $t$ & $p$ \\
\hline \multirow{2}{*}{ Initial } & $\mathrm{R}$ & 5 & $\begin{array}{c}6,30 \\
\pm \\
0,34\end{array}$ & \multirow{2}{*}{0,98} & \multirow{2}{*}{$\overrightarrow{0,05}$} \\
\hline & $\mathrm{U}$ & 22 & $\begin{array}{c}6,72 \\
\pm \\
0,27\end{array}$ & & \\
\hline \multirow{2}{*}{ Intermediary } & $\mathrm{R}$ & 5 & $\begin{array}{c}6,90 \\
\pm \\
036\end{array}$ & \multirow{2}{*}{0,94} & \multirow{2}{*}{$\overrightarrow{0,05}$} \\
\hline & $\mathrm{U}$ & 22 & $\begin{array}{c}7,36 \\
\pm \\
0,33\end{array}$ & & \\
\hline \multirow{2}{*}{ Final } & $\mathrm{R}$ & 5 & $\begin{array}{c}7,40 \\
\pm \\
0,36\end{array}$ & \multirow{2}{*}{1,20} & \multirow{2}{*}{$\stackrel{>}{0,05}$} \\
\hline & $\mathrm{U}$ & 22 & $\begin{array}{c}7,93 \\
\pm \\
0,26\end{array}$ & & \\
\hline \multicolumn{6}{|c|}{$\begin{array}{r}\text { Legend: } \mathbf{R} \text { - rural, } \mathbf{U} \text { - urban } \\
\qquad \mathrm{p}-0,05 ; 0,\end{array}$} \\
\hline
\end{tabular}

From a statistical point of view, regarding the type of subjects recruited in the pedagogical experiment, the Student Test shows that, in the case of the experimental class, there are no significant differences between the girls 'averages and the boys' averages both in the $10^{\text {th }}$ grade (girls: $x=7,08$, boys : $x=6,30$ ) and in the $12^{\text {th }}$ grade (girls: $\mathrm{x}=8,25$, boys: $\mathrm{x}=7,50$ ), for $\mathrm{t}(25)$ $=1,55, \mathrm{p}>0,05$ at the initial testing and $\mathrm{t}(25)=1.48, \mathrm{p}>$ 0.05 at the final testing.

At the level of the $11^{\text {th }}$ grade, corresponding to the intermediary evaluation, after the introduction of the experimental method, the Student Test shows that the girls' averages $(\mathrm{x}=8,00)$ increase significantly from the boys' averages $(\mathrm{x}=6,70) 2.56$, for $\mathrm{t}(25)=2,56, \mathrm{p}<$ 0,05 .

In interpreting the background indicators, the Student Test reveals that there are no significant statistical differences within the experimental group among the environments of rural and urban subjects in any of the three forms of evaluation. Thus, in the initial test for $\mathrm{t}(25)=0.63, \mathrm{p}>0.05$, for the intermediate test $\mathrm{t}$ $(25)=0.64, p>0.05$ and for the final test $t(25) 79, p>$ 0.05 .

Table 2. Comparative results between the gender and provenience environment of the subjects in the control group, within the initial, intermediate and final testing $(n=28)$

\section{STATISTICAL INDICATORS BY GENDER}

\begin{tabular}{|c|c|c|c|c|c|}
\hline $\begin{array}{c}\text { Evaluation } \\
\text { forms }\end{array}$ & $\begin{array}{c}\text { Gender: } \\
\mathbf{M} / \mathbf{F}\end{array}$ & $\boldsymbol{n}$ & $\begin{array}{c}\bar{X} \pm \\
\boldsymbol{m}\end{array}$ & $\boldsymbol{t}$ & $\boldsymbol{p}$ \\
\hline Initial & $\mathrm{M}$ & & $\begin{array}{c}6,07 \pm \\
0,37\end{array}$ & & \\
\hline
\end{tabular}

\begin{tabular}{|c|c|c|c|c|c|}
\hline & & 14 & & 1,68 & $>$ \\
\cline { 2 - 4 } & $\mathrm{F}$ & 14 & $\begin{array}{c}6,85 \pm \\
0,28\end{array}$ & 0,05 \\
\hline \multirow{4}{*}{ Intermediary } & $\mathrm{M}$ & 14 & $\begin{array}{c}6.14 \pm \\
0.37\end{array}$ & & \\
\cline { 2 - 4 } & $\mathrm{F}$ & 14 & $\begin{array}{c}7.00 \pm \\
0.26\end{array}$ & 1,85 & 0,05 \\
\hline \multirow{3}{*}{ Final } & $\mathrm{M}$ & 14 & $\begin{array}{c}6.28 \pm \\
0.38\end{array}$ & & \\
\cline { 2 - 4 } & $\mathrm{F}$ & 14 & $\begin{array}{c}7.14 \pm \\
0.30\end{array}$ & 1,76 & 0,05 \\
\hline
\end{tabular}

\begin{tabular}{|c|c|c|c|c|c|}
\hline \multicolumn{6}{|c|}{$\begin{array}{l}\text { STATISTICAL INDICATORS BY } \\
\text { PROVENIENCE ENVIRONMENT }\end{array}$} \\
\hline $\begin{array}{l}\text { Evaluation } \\
\text { forms }\end{array}$ & $\begin{array}{c}\text { Provenience } \\
\text { environment } \\
\text { : } \\
\text { R / U }\end{array}$ & $n$ & $\begin{array}{l}\bar{X} \\
\pm m\end{array}$ & $t$ & $p$ \\
\hline \multirow{2}{*}{ Initial } & $\mathrm{R}$ & $\begin{array}{l}1 \\
9\end{array}$ & $\begin{array}{c}6.0 \\
0 \pm \\
0.3 \\
2\end{array}$ & \multirow{2}{*}{$\begin{array}{c}2,8 \\
2\end{array}$} & \multirow{2}{*}{$\begin{array}{c}< \\
0,0 \\
1\end{array}$} \\
\hline & $\mathrm{U}$ & 9 & $\begin{array}{c}7.4 \\
4 \pm \\
0.4 \\
0\end{array}$ & & \\
\hline \multirow{2}{*}{$\begin{array}{l}\text { Intermediar } \\
\mathbf{y}\end{array}$} & $\mathrm{R}$ & $\begin{array}{l}1 \\
9\end{array}$ & $\begin{array}{c}6.1 \\
3 \pm \\
0.3 \\
3\end{array}$ & \multirow{2}{*}{$\begin{array}{c}2,6 \\
3\end{array}$} & \multirow{2}{*}{$\begin{array}{c}< \\
0,0 \\
5\end{array}$} \\
\hline & $\mathrm{U}$ & 9 & $\begin{array}{c}7.5 \\
0 \pm \\
0.4 \\
0\end{array}$ & & \\
\hline \multirow{2}{*}{ Final } & $\mathrm{R}$ & 9 & $\begin{array}{c}6.2 \\
3 \pm \\
0.3 \\
4\end{array}$ & \multirow{2}{*}{$\begin{array}{c}2,7 \\
6\end{array}$} & \multirow{2}{*}{$\begin{array}{c}< \\
0,0 \\
5\end{array}$} \\
\hline & $\mathrm{U}$ & 9 & $\begin{array}{c}7.7 \\
2 \pm \\
0.4 \\
2\end{array}$ & & \\
\hline Legend: $\mathrm{R}-$ & $\begin{array}{l}\text { al, U - urban } \\
\mathrm{p}-0,05 \\
\mathrm{t}=2,056\end{array}$ & & $\begin{array}{l}0,00 \\
3,70\end{array}$ & & \\
\hline
\end{tabular}

The Student Test shows, statistically, that there are no significant differences between girls' averages and boys' averages for the $10^{\text {th }}$ and $12^{\text {th }}$ grades. At the level of the $11^{\text {th }}$ grade, the girls' averages $(x=7,00)$ increase significantly from the average of the boys $(\mathrm{m}=$ $6,14)$, for $\mathrm{t}(26)=1,85, \mathrm{p}<0,05$.

Between the averages of the students from the rural and urban environments there are statistically significant differences across the control class at all three levels of education $\left(10^{\text {th }}, 11^{\text {th }}\right.$, and $12^{\text {th }}$ grade $)$. For $10^{\text {th }}$ grade, the average of those in the urban 
environment $(x=7,44)$ is significantly higher than in the rural area $(x=6,00), t(26)=3,25, \mathrm{p} \leq 0,05$. The same progress is recorded in the $11^{\text {th }}$ grade, where the average of those in the urban environment $(x=7,50)$ increases significantly compared to the ones in the rural environment $(x=6,13), t(26)=3.02, p \leq 0.05$, and in the $12^{\text {th }}$ grade, where the average of the subjects in the urban environment $(\mathrm{x}=7.44)$ record the most significant increases compared to those in rural environment $(\mathrm{x}=6,00), \mathrm{t}(26)=3,25, \mathrm{p} \leq 0,05$.

As for the subject genes, in the case of the experimental class, there are no significant differences between initial testing and final testing. However, it draws attention to the first experimental year, at the level of the $11^{\text {th }}$ grade, corresponding to the intermediary evaluation, when the performance of the girls is superior to that of the boys, after the introduction of the experimental method. As a possible interpretation, this could mean that in the initial phase of the pedagogical experiment the girls quickly understood/acquired the experimental method compared to boys. However, as in the $12^{\text {th }}$ grade there are no significant differences, this advance has most likely faded over the course.

In fact, a similar differentiation situation is also found in the girls of the $11^{\text {th }}$ grade in the control class, at the same level of testing (intermediate testing). This suggests that the earlier interpretation related to the experimental method is most likely to be wrong, according to which the girls have acquired the experimental method faster than the boys. The progress could be explained by the existence of common psychological variables available to subjects aged 16-18 $[3,4]$ between the two classes of subjects, which favoured the temporary acceleration of the learning rate of the girls during the $11^{\text {th }}$ grade.

If there are no statistically significant differences between the averages of the subjects from the rural and urban environments in the experiment class, the difference between the three levels of education $\left(10^{\text {th }}\right.$, $11^{\text {th }}$ and $12^{\text {th }}$ grades). Thus, the average of the subjects from the urban environment increases significantly at each level of training, compared to those in rural environment where progress is almost zero. This leads to the idea that the traditional didactic strategies used in the teaching process in the control class are better suited for those in the urban environment than for those in the rural one.

As regards the low level of knowledge and intellectual skills (prior to the experiment) of the students in the control class from the rural environment, the explanations could be determined by a number of factors of a family nature, of a physio-psychosociological nature, of a pedagogical nature [2].

\section{Conclusions}

If the initial testing between the experiment group and the control group did not reveal statisticalmathematical differences ( $>>0,05)$, after the introduction of the didactic methods of experimental character, the first changes were noted: in the intermediate testing: $\mathrm{p}<0.05$, and in final testing: $\mathrm{p}$ $<0,01$.

In the experimental group there were no significant differences between the girls' averages and the boys' averages, both in initial testing and in final testing. However, in the intermediate testing, after the introduction of the experimental strategies, the girls' averages increased significantly compared to the boys' average, the same aspect being also reported in the control group.

As for the subject's provenience environment, if there are no statistically significant differences between the averages of the subjects from the rural and urban environments in all three types of testing $(p>0,05)$ in the control class $(p<0,01$ in the initial test, $p<0,05$ in the intermediate test, $p<0,05$ in the final test), the average of the subjects coming from the urban environment rising from one experimental year to another, compared to the subjects from the rural environment, where progress is almost zero from a statistical-mathematical point of view.

\section{References}

1.Balica M., Fartuşnic C., Horga I., Jigău M., Voinea L. (2004), Perspective asupra dimensiunii de gen $\hat{i n}$ educaţie. Institutul de Ştiinţe ale Educaţiei, UNICEF în România. București, Editura MarLink, p. 9-11.

2.Bontaş I. (2008), Tratat de pedagogie, Bucureşti, Editua ALL, p. 274-275.

3.Cosmovici A., Iacob L. (1999), Psihologie şcolară, Iaşi, Editura Polirom, p. 49-52.

4. Hayes N., Orrell S. (2003), Introducere in psihologie. Ediţia a III-a, Bucureşti, Editura BIC ALL, p. 7-8.

5.Labăr A.V. (2008), SPSS pentru ştiinţele educaţiei. Metodologia analizei datelor in cercetarea pedagogică. Iaşi, Editura Polirom, p. 95-102.

6.Popa M. (2008), Statistică pentru psihologie. Teorie şi aplicaţii SPSS. Ediția a II-a revăzută și adăugită. Iaşi, Editura Polirom, p. 291-308. 